\title{
A UTOREFERATY
}

\section{Kamil Piskała}

\section{Ku Rzeczypospolitej Socjalistycznej. Studium z dziejów myśli politycznej PPS (1929-1939)*}

Dekada lat trzydziestych w dziejach Europy upłynęła pod znakiem kryzysu gospodarczego oraz - dojrzewających w jego cieniu - głębokich przesileń politycznych i społecznych. Była to dekada pełna niepokoju, politycznych radykalizmów oraz gwałtownych sporów ideowych, prowadzących nierzadko do daleko idącej polaryzacji opinii i ostrych antagonizmów. Polskie życie polityczne pod tym względem nie stanowiło wyjątku. Lata trzydzieste to czas ożywionych dyskusji publicystycznych, przewartościowań na scenie partyjnej oraz rewizji wielu założeń programowych tradycyjnie przyjmowanych przez przywódców czy ideologów poszczególnych obozów politycznych. Choć polski ruch socjalistyczny, którego polityczny rdzeń stanowiła Polska Partia Socjalistyczna (PPS), uniknął ostatecznie w tym okresie spektakularnych rozłamów czy gwałtownych wolt programowych, to i w jego wypadku można mówić o istotnym przesileniu ideowym i towarzyszącej mu intensyfikacji wewnętrznych debat oraz dyskusji teoretycznych. Ich swoistym podsumowaniem był nowy program PPS, uchwalony w lutym 1937 r. na zjeździe w Radomiu (stąd popularnie nazywany „programem radomskim”), wysuwający jako bezpośredni postulat budowę „Polskiej Rzeczypospolitej Socjalistycznej”

\footnotetext{
* Autoreferat rozprawy doktorskiej obronionej na Wydziale Filozoficzno-Historycznym Uniwersytetu Łódzkiego 20 VI 2017 r. Promotorem rozprawy był prof. nadzw. dr hab. Przemysław Waingertner, recenzentami zaś: prof. dr hab. Michał Śliwa oraz prof. nadzw. dr hab. Rafał Chwedoruk.

${ }^{1}$ Program Polskiej Partii Socjalistycznej uchwalony przez XXIV Kongres $w$ Radomiu dnia 2-go lutego 1937, Warszawa 1937, s. 2.
} 
Na znaczenie omawianego okresu w rozwoju myśli politycznej PPS i na szeroki zakres toczonej wówczas wśród socjalistów debaty programowej wielokrotnie zwracano uwagę - choć zwykle w sposób pośredni - w istniejącej literaturze ${ }^{2}$. Nie traktowano przy tym jednak dekady lat trzydziestych jako wyraźnie wyodrębnionego przedmiotu badania, tym bardziej zaś nie podjęto próby systematycznego przebadania dynamiki zachodzących wówczas przemian w myśli politycznej PPS. Uwaga badaczy skupiała się zwykle na dyskusjach toczonych wokół taktyki, jaka powinna stosować PPS, i coraz radykalniejszych haseł wysuwanych przez część przynajmniej spośród jej działaczy czy publicystów ${ }^{3}$. Tego rodzaju ujęcia, choć często o dużej wartości dokumentacyjnej i ważne z perspektywy rekonstrukcji ogólnego przebiegu publicystycznych dyskusji prowadzonych przez socjalistów, zwykle jednak pomijały szerszy kontekst przemian zachodzacych w myśli socjalistycznej, widząc w nowych hasłach i nowych, zwykle bardziej radykalnych postulowanych metodach działania rezultat typowej dla okresu gospodarczego i społecznego kryzysu radykalizacji nastrojów czy też oczywistą odpowiedź na kolejne polityczne niepowodzenia samej PPS. Jak jednak wskazuja badania prowadzone nad ideologia partii socjalistycznych $\mathrm{w}$ innych krajach europejskich w tym czasie, a potwierdzają to również wnioski wyciagnięte ze wstępnej analizy podstawowych źródeł do dziejów myśli politycznej PPS w tym okresie, wydarzenia lat trzydziestych i wyzwania, jakie niósł ten okres, stworzyły presję, pod wpływem której w myśli socjalistycznej zachodziła głęboka i - jak się miało w wielu wypadkach okazać - trwała transformacja.

Tego rodzaju spostrzeżenia były punktem wyjścia opracowania rozprawy poświęconej myśli politycznej PPS w latach 1929-1939, stawiającej sobie za cel omówienie i analize przemian zachodzących w jej obrębie, stanowiacych bezpośredni kontekst, a często też przyczynę, toczonych w tym okresie w szeregach PPS sporów o taktykę działania, dobór haseł, którymi należało operować w bieżącej agitacji, oraz metody realizacji własnych celów politycznych. Trzeba bowiem też zauważyć, że choć porzucono częściowo już retorykę „naukowości”, charakterystyczną dla epoki II Międzynarodówki, to w okresie

\footnotetext{
${ }^{2}$ Początek dekady lat trzydziestych stanowi na przykład jedną z cezur wewnętrznych przyjętych w studium polskiej myśli socjalistycznej lat 1918-1948, autorstwa wybitnego znawcy tej problematyki, Michała Śliwy. Por. M. Śliwa, Polska myśl socjalistyczna (1918-1948), Wrocław 1988, s. 138.

${ }^{3}$ Badania nad tzw. lewica socjalistyczną i dążeniem do zacieśniania współpracy z ruchem komunistycznym szczególnie często podejmowano przed 1989 r., co było zresztą zbieżne z oficjalną narracją o najnowszej historii Polski, rozwijaną w kręgu intelektualistów i publicystów związanych z PZPR. W radykalizacji sporej części działaczy PPS w latach trzydziestych dostrzegano więc wówczas przede wszystkim przejaw pozytywnych tendencji i zapowiedź przyszłego „zjednoczenia” ruchu robotniczego. Zwykle jednak na takich spostrzeżeniach poprzestawano, rezygnując z bardziej kompleksowej analizy, biorącej za punkt wyjścia ideowe przemiany w samym ruchu socjalistycznym, a nie oczekiwania, jakie względem socjalistów formułowano w kręgu przywódców ruchu komunistycznego.
} 
międzywojennym ruch socjalistyczny w całej Europie - PPS nie była pod tym względem wyjątkiem - aspirował wciąż do tego, aby swa taktykę i bieżące posunięcia polityczne opierać na szerokich uzasadnieniach teoretycznych i kompleksowej analizie rzeczywistości ekonomiczno-społecznej oraz jej przemian. I nawet jeśli uznamy, że „teoria” bywała w takich sytuacjach często służebna wobec wcześniejszej praktyki (zasadniczo była to zapewne relacja dialektyczna), to zdaje się nie ulegać wątpliwości, że stanowi ona kontekst, bez którego nie sposób właściwie rozumieć taktycznych wyborów i dyskusji polskich socjalistów.

Tak zarysowany zasadniczy cel pracy uzupełnił oczywiście katalog szczegółowych pytań i problemów badawczych, którym posiłkowano się w toku analizy gromadzonego materiału źródłowego. Przy jego konstruowaniu zwrócono uwagę $\mathrm{m}$.in. na zmienne i stałe elementy $\mathrm{w}$ formułowanej przez socjalistów diagnozie systemu kapitalistycznego, zróżnicowanie wyobrażeń i opinii na temat jego dynamiki i historycznej trajektorii, sposób opisu i rozumienia źródeł procesów społecznych, dyskusje wokół pożądanych przez socjalistów modeli zmiany społecznej, przemiany w sposobie analizowania sił klasowych, podejścia socjalistów do problemów mobilizacji politycznej, opinie na temat mechanizmów oraz dynamiki walki klasowej i wreszcie, logiczne zwiąki zachodzace pomiędzy ewolucją $\mathrm{w}$ dziedzinie analiz o bardziej teoretycznym charakterze a wysuwanymi przez socjalistów hasłami czy postulowanymi metodami praktycznego działania. Tym samym można powiedzieć, że podejmowanym $\mathrm{w}$ omawianej rozprawie rozważaniom przyświecało pragnienie uchwycenia - na ile jest to możliwe - systemowej logiki rządzącej przemianami zachodzącymi w myśli politycznej PPS w latach trzydziestych, znajdującej też swój zewnętrzny wyraz w takich lub innych postulatach, hasłach i politycznych inicjatywach socjalistów.

Tak nakreślony przedmiot i cele rozprawy w decydujący sposób wpłynęły na przyjętą w niej strukturę prezentacji materiału. Dążąc z jednej strony do uchwycenia dynamiki omawianych przemian w myśli politycznej PPS, z drugiej zaś chcąc toczone przez socjalistów dyskusje wpisać $\mathrm{w}$ możliwie szeroki kontekst teoretyczny i uchwycić tym samym związki zachodzace pomiędzy zmianami dokonującymi się na różnych poziomach refleksji prowadzonej przez przywódców i publicystów PPS, zdecydowano się na podział pracy na rozdziały problemowe, w ramach nich zaś zasadniczo porządkowano wywód podług kryterium chronologicznego. Wybór taki, choć wiążacy się z niemożliwym do uniknięcia ryzykiem pewnych powtórzeń, mimo wszystko zdaje się lepiej odpowiadać celom stawianym przed niniejsza praca, niż alternatywa w postaci klasycznego układu chronologicznego.

Podkreślić należy przy tym, że dążenie socjalistów do objaśniania i uzasadniania konkretnych posunięć politycznych w szerokim, teoretycznym kontekście wiązało się z samą strukturą rozwijanej przez ówczesny ruch socjalistyczny refleksji programowej. Tworzyła ona spójna, przynajmniej na 
ogólnym poziomie, całość zawierająca szereg tez i założeń dotyczących najogólniejszych właściwości charakteryzujących społeczną rzeczywistość, zasadniczo mających wynikać, jak twierdzili socjaliści - będąc pod tym względem wiernymi kontynuatorami Marksa i jego epigonów spod znaku II Międzynarodówki ${ }^{4}-\mathrm{z}$ aktualnie istniejących sposobów i stosunków produkcji. Tę specyficzną strukturę myśli politycznej socjalistów - co też wyróżniało ich na tle większości konkurencyjnych obozów politycznych - dobrze ilustruje kształt ówczesnych programów socjalistycznych, pod względem zasady konstrukcyjnej dość podobnych do siebie, niezależnie od lokalnych warunków danego kraju. Krótko- oraz długoterminowe cele polityczne, deklarowane metody działania i praktyczne postulaty ruchu z założenia wyprowadzane były $\mathrm{w}$ tego rodzaju dokumentach (abstrahujacc od tego, na ile przekonująco to czyniono) z ogólnych diagnoz odnoszących się do natury i dynamiki przemian systemu kapitalistycznego oraz formułowanych na tej podstawie analiz układu sił klasowych, prognoz dotyczacych przyszłych przesunięć w tej sferze, a także oceny ustrojowych form, w ramach których toczone były zmagania pomiędzy poszczególnymi klasami i warstwami społecznymi.

$\mathrm{W}$ związku z tym wydzielone $\mathrm{w}$ pracy rozdziały odpowiadają niejako poziomom czy też „warstwom” programowej refleksji socjalistów. Pierwszy z nich poświęcony jest wobec tego prowadzonym przez socjalistów rozważaniom na temat przemian w życiu gospodarczym w kontekście ewolucji systemu kapitalistycznego, dyskusji na temat sposobów organizacji ładu gospodarczego po jego zniesieniu oraz użyteczności poszczególnych metod polityki gospodarczej w realizacji najważniejszego celu ruchu, a więc przejścia do socjalistycznego sposobu produkcji. Warto zauważyć, że w pierwszej powojennej dekadzie socjaliści żywili przekonanie o naturalnym kształtowaniu się obiektywnych, a więc właśnie gospodarczych, przesłanek przyszłego ładu socjalistycznego w rezultacie działania mechanizmów rozwojowych kapitalizmu. Uzasadnienie dla tego rodzaju poglądów stanowić miała przede wszystkim postępująca koncentracja produkcji oraz dyspozycji gospodarczej, co znajdowało wyraz m.in. w procesie kartelizacji. Teoria „kapitalizmu zorganizowanego”, sformułowana przez jednego z przywódców Socjaldemokratycznej Partii Niemiec (SPD), Rudolfa Hilferdinga ${ }^{5}$, a bliska również polskim socjalistom w tym okresie, zakładała z jednej strony ewolucyjne kształtowanie się gospodarczych przesłanek socjalizmu, z drugiej zaś pozwalała skupić uwagę socjalistów na walce o wpływ na politykę państwa, w praktyce zaś na zmaganiach o możliwie wysoką liczbę mandatów parlamentarnych. Wybuch globalnego

\footnotetext{
${ }^{4}$ Jak zauważa Roman Bäcker, „Można PPS traktować [...] jako partię o charakterze wyraźnie marksistowskim i to w tym nurcie, który jest najbardziej ortodoksyjny, bo skodyfikowany przez Karola Kautskiego". R. Bäcker, Problematyka państwa w polskiej myśli socjalistycznej lat 1918-1948, Toruń 1994, s. 138-139.

5 Szerzej na temat teorii „kapitalizmu zorganizowanego” i jej konsekwencji zob. W. Smaldone, Rudolf Hilferding. The Tragedy of a German Social Democrat, DeKalb 2015, s. 101-108.
} 
kryzysu gospodarczego, a później jego długotrwały charakter i bezprecedensowa skala zmusiły socjalistów do poważniejszej analizy kondycji systemu kapitalistycznego i rewizji części przyjmowanych założeń. W rozdziale tym omówiono wobec tego m.in. dyskusje, jakie socjaliści prowadzili na temat przyczyn kryzysu, a także przesłanki, które ich zdaniem przemawiać miały za uznaniem jego systemowego charakteru. Konsekwencją tezy o systemowym charakterze kryzysu, a więc o niemożności przywrócenia równowagi i stabilnego wzrostu w ramach gospodarki kapitalistycznej, było rosnace zainteresowanie socjalistów alternatywnymi sposobami organizacji produkcji i perspektywami ustanowienia gospodarki uspołecznionej. Warto też zauważyć, że pomimo wejścia w okres zdecydowanie lepszej koniunktury w drugiej połowie lat trzydziestych, socjaliści nie odrzucili tezy o systemowym kryzysie kapitalizmu, w związku z czym też w aktywnej, stymulującej popyt na rynku wewnętrznym, polityce realizowanej przez rządy części państw europejskich dostrzegali nie tyle próbę przywrócenia strukturalnej równowagi w ramach gospodarki kapitalistycznej, ile raczej zapowiedź przejścia do gospodarki uspołecznionej, działającej w oparciu o dążenie do maksymalizacji społecznej korzyści, nie zaś w oparciu o pragnienie maksymalizacji prywatnego zysku.

Drugi rozdział rozprawy poświęcony został omówieniu dyskusji i poglądów socjalistów, dotyczących strategicznych uwarunkowań prowadzonej przez nich polityki, a więc kwestii ustrojowych i wpływu formy państwa na dynamikę konfliktów klasowych, oraz przemianom zachodzącym w układzie sił społecznych. Socjaliści tradycyjnie uważali, że demokracja parlamentarna tworzy stosunkowo najlepsze warunki dla wzrostu politycznej siły klasy robotniczej, wierząc przy tym, że w ramach demokratycznych instytucji możliwe będzie pokojowe i łagodne ustanowienie nowego, socjalistycznego porządku. Z tego też względu PPS konsekwentnie broniła systemu demokratycznego, stając się siła, wokół której w różnych okresach krystalizowały się środowiska demokratyczne. Początek lat trzydziestych, wraz ze wzrostem ruchów faszystowskich i autorytarnych, zachwiał jednak wiarę socjalistów w skuteczność mechanizmów demokracji parlamentarnej, funkcjonujących $\mathrm{w}$ warunkach trwania, pograżonego w kryzysie, kapitalizmu. W szeregach PPS szczególnie ostro krytykę nadmiernych nadziei wiązanych z powojenna demokracja parlamentarna przeprowadzono na początku lat trzydziestych pod wrażeniem wyborów brzeskich oraz upadku demokracji w Niemczech. Nie oznacza to jednak, że PPS zwróciła się przeciwko idei demokracji. Przeciwnie, jej liderzy i ideolodzy uważali, że przyszłość demokracji jest ściśle związana ze zwycięstwem ruchu socjalistycznego, bowiem w warunkach trawionego przez kryzys kapitalizmu przestała ona być dla burżuazji użyteczna forma rządów, a wobec tego ulega faszyzmowi.

Polityczne wstrząsy z początku lat trzydziestych zmusiły również socjalistów do podjęcia na nowo analizy układu sił klasowych. Dość powszechnie przyjęto tezę, forsowaną szczególnie przez Mieczysława Niedziałkowskiego, 
że wobec „przedwczesnego”, w zestawieniu z dotychczas żywionymi w szeregach socjalistów przekonaniami, upadku kapitalizmu o wyniku historycznych zmagań, w których stawka zdawała się przyszłość europejskich społeczeństw, zadecydują nie tylko siły i determinacja klas, którym tradycyjnie przypisywano w myśli socjalistycznej historyczną sprawczość - a więc robotników i burżuazji - lecz również, a jak chciał Niedziałkowski, nawet przede wszystkim, stanowisko zajęte przez tzw. warstwy pośrednie. Istotna część tego rozdziału pracy poświęcona została właśnie omówieniu różnych stanowisk socjalistów w kwestii możliwych sposobów politycznej mobilizacji tzw. warstw pośrednich i przypadającej im w warunkach systemowego kryzysu kapitalizmu historycznej roli. Analizie poddano istotną treść programową dyskusji wokół dyktatury proletariatu, budzacej w latach trzydziestych szczególne kontrowersje, a przyciagającej również uwagę zewnętrznych komentatorów przez jej pryzmat (podobnie zresztą czyniła część powojennej historiografii) oceniających przebieg złożonego i wielowymiarowego przesilenia programowego w szeregach PPS.

Trzeci wreszcie rozdział pracy poświęcony został problematyce stosunkowo najchętniej podejmowanej przez dotychczasowych badaczy, a więc politycznej taktyce PPS w omawianym okresie i wysuwanym przez socjalistów hasłom agitacyjnym. Należy jednak przy tym zdecydowanie podkreślić, że zrezygnowano tutaj zasadniczo ze szczegółowego omawiania faktycznie prowadzonej przez PPS polityki - tę problematykę zadowalająco omówili Bogdan Głowacki ${ }^{6}$ i Janusz Żarnowski ${ }^{7}$ - główny nacisk położono natomiast na dyskusje i spory wokół kwestii taktycznych, a także na rekonstrukcję szerszych politycznych scenariuszy, które dostarczały uzasadnień dla konkretnych propozycji działania. Szczególnie wiele miejsca poświęcono tu, co zrozumiałe, odbywanym w tym okresie kongresom PPS $(1931,1934,1937)$ i towarzyszącym im dyskusjom, to wówczas bowiem najpełniej dawały o sobie znać różnice stanowisk, a polemiczne napięcie było najsilniejsze. Wówczas też zapadały istotne decyzje dotyczące polityki partii na najbliższe miesiące.

Rozprawę wieńczy obszerne, liczące 20 stron, zakończenie, w którym wyartykułowano wnioski płynące z prowadzonych w pracy rozważań, a także podjęto próbę zintegrowania najważniejszych wątków podejmowanych w poszczególnych rozdziałach $\mathrm{w}$ odniesieniu do wyodrębnionych $\mathrm{w}$ celach analitycznych płaszczyzn refleksji programowej socjalistów, tak aby zgodnie ze stawianymi celami naszkicować ogólną trajektorię przemian dokonujacych się w tym okresie w myśli politycznej PPS. Całość uzupełniają wykaz stosowanych skrótów i obszerna bibliografia zawierająca tytuły przywoływanych prac oraz zestawienie wykorzystanych przy opracowywaniu rozprawy źródeł.

Podstawowy korpus źródeł, dla podejmowanego w rozprawie tematu i stawianych przed nią celów, stanowiły różnego rodzaju dokumenty programowe

${ }_{6}^{6}$ B. Głowacki, Polityka Polskiej Partii Socjalistycznej 1929-1935, Warszawa 1979.

7 J. Żarnowski, Polska Partia Socjalistyczna w latach 1935-1939, Warszawa 1965. 
PPS oraz znacznie bogatsza oczywiście pod względem objętości publicystyka wychodzacca w omawianym okresie spod piór związanych z tą partią działaczy i ideologów. Wśród różnych typów źródeł na czoło wysunęła się wobec tego prasa, z jednej strony przedrukowujacca - z myśla o sympatykach i szeregowych działaczach PPS - najważniejsze enuncjacje programowe uchwalane przez partyjne gremia, z drugiej zaś stanowiąca miejsce możliwie pełnej i niezapośredniczonej prezentacji stanowisk ideowych przywódców i publicystów socjalistycznych, a także arenę części przynajmniej spośród toczonych przez nich polemik czy dyskusji. Szczególnie uważną analizę prasy uzasadniają również dotychczasowe doświadczenia historiografii poświęconej myśli politycznej II Rzeczypospolitej, wskazujące na kluczowe znaczenie źródeł prasowych dla rekonstrukcji ideowej panoramy polskiego życia politycznego tego okresu .

Z myślą o stworzeniu możliwie pełnego i wielopłaszczyznowego obrazu debat i kontrowersji ideowych w polskim ruchu socjalistycznym w omawianym okresie przeprowadzono pogłębioną kwerendę prasowa, obejmującą łącznie 35 tytułów, poczynając od najważniejszych i najbardziej wpływowych pism socjalistycznych (,Robotnik”, „Światło”, „Naprzód”, „Tydzień Robotnika”), poprzez periodyki lokalne (np. „Wyzwolenie Społeczne” z Białej, „Nowy Głos Przemyski”, radomskie „Życie Robotnicze”), pisma klasowego ruchu zawodowego („Robotniczy Przegląd Gospodarczy”, „Włókniarz”), a na prasowych efemerydach związanych ze środowiskiem PPS skończywszy („Kwartalnik Socjalistyczny”, „Głos Stolicy”). Łącznie w rezultacie kwerendy wytypowano ok. 4,5 tys. artykułów o charakterze publicystycznym, które następnie stały się podstawa prac analitycznych i bazą obszernych partii rozprawy.

Inną formą prezentacji poglądów i stanowisk czołowych ideologów PPS były prace zwarte - książki i broszury - których łącznie w omawianym okresie ukazało się kilkanaście, m.in. Zygmunta Zaremby, Mieczysława Niedziałkowskiego, Jana Maurycego Borskiego, Zygmunta Żuławskiego, Daniela Grossa czy Mariana Porczaka. Wszystkie one wykorzystane zostały w szerokim zakresie przy opracowywaniu odpowiednich partii tekstu. Pomocniczą rolę odegrały również publikowane już po 1945 r. wybory artykułów i przemówień niektórych ważniejszych działaczy socjalistycznych, stanowiace rezultat prowadzonych wówczas prac dokumentacyjnych dotyczących dziejów polskiego ruchu robotniczego. W formie osobnych tomów opracowano wtedy m.in. publicystykę Adama Próchnika, Stanisława Dubois czy Norberta Barlickiego. Kategorię źródeł drukowanych uzupełniaja publikowane w formie odrębnych druków poszczególne dokumenty programowe polskiego ruchu socjalistycznego oraz sprawozdania z posiedzeń władz PPS, a także diariusze sejmowe i senackie za lata 1929-1935.

\footnotetext{
${ }^{8}$ Por. A. Paczkowski, Badania historycznoprasowe $w$ zastosowaniu do badań nad dziejami myśli politycznej, w: Polska myśl polityczna XIX $i$ XX wieku, t. IV: Na warsztatach historyków polskiej myśli politycznej, red. H. Zieliński, Wrocław 1980, s. 9.
} 
Źródła archiwalne, w badaniach z zakresu historii najnowszej zwykle wymieniane jako pierwsze i traktowane jako najważniejsze, w przypadku niniejszej rozprawy miały mniejsze znaczenie. To zreszta, jak już zasugerowano, sytuacja dość typowa dla badań nad dziejami międzywojennej myśli politycznej. Tylko stosunkowo niewielka część zachowanych do dzisiaj archiwaliów dotyczących życia politycznego tego okresu wytworzona została bowiem bezpośrednio przez struktury działających wówczas ugrupowań, a jeśli nawet tak się działo, to zwykle sa to materiały o charakterze agitacyjnym albo też dokumenty związane z bieżącą działalnościa organizacyjna, rzadko zaś tylko oryginalne świadectwa rozwoju myśli politycznej. Nie inaczej wygląda to w przypadku PPS - wśród zachowanych archiwaliów dotyczących działalności tej partii w latach 1929-1939 tylko znikomą część stanowią te, które wytworzyli sami socjaliści. Przechowywany w warszawskim Archiwum Akt Nowych zespół o nazwie Archiwum Polskiej Partii Socjalistycznej (tzw. archiwum londyńskie), poza pojedynczymi (i nieistotnymi z punktu widzenia tej pracy) dokumentami, nie obejmuje w zasadzie materiałów wytworzonych po 1929 r. Skromna jest również dla tego okresu zawartość zespołu Polska Partia Socjalistyczna 1919-1939, choć w tym wypadku kwerenda okazała się nieco bardziej owocna, przede wszystkim dzięki zbiorowi urzędowych odpisów okólników rozsyłanych do terenowych organizacji przez Centralny Komitet Wykonawczy partii w drugiej połowie lat trzydziestych.

Dokumenty władz administracyjnych, rejestrujących najważniejsze wydarzenia z działalności i życia organizacyjnego stronnictw politycznych, miały dla niniejszej pracy znaczenie tylko pomocnicze. Choć spuścizna tego rodzaju jest stosunkowo obszerna, to ze względu na swoją specyfikę tylko w ograniczonym stopniu pozwala śledzić ideowe kontrowersje i programowe przewartościowania w szeregach socjalistów, wyłaniający się z niej obraz jest zaś niepełny i zawsze skrojony na potrzeby władz administracyjnych, a zazwyczaj również obciążony z powodu ograniczonych kompetencji autorów poszczególnych sprawozdań, niedostrzegających zwykle niuansów relacjonowanych przez siebie sporów czy dyskusji. Mimo jednak wszystkich tych zastrzeżeń przeprowadzoną na potrzeby niniejszej rozprawy kwerendę archiwalną uznać należy za obszerna, łącznie bowiem zestawienie wykorzystanych archiwaliów obejmuje 22 zespoły i zbiory przechowywane w 10 różnych placówkach (m.in. AAN, Archiwum Państwowe w Krakowie, Archiwum Państwowe w Warszawie, Archiwum Państwowe w Lublinie, Archiwum Państwowe w Łodzi, Archiwum Państwowe w Kielcach, Zakład Narodowy im. Ossolińskich). Ponadto bazę źródłowa uzupełniły drukowane wspomnienia i relacje, ich znaczenie jednak dla prowadzonych analiz i formułowanych wniosków było stosunkowo najmniejsze.

$\mathrm{W}$ prezentowanej rozprawie, na co zresztą wskazuja już rozmiary bibliografii cytowanych prac, obficie korzystano z ustaleń innych badaczy i badaczek zajmujących się dziejami polskiego ruchu socjalistycznego. Szczególnie ważny punkt odniesienia stanowiły prace Michała Śliwy, od lat prowadzącego 
intensywne badania nad dziejami polskiego ruchu socjalistycznego, formułowana w jego ramach myśla polityczną i zwłaszcza nad koncepcjami czołowego teoretyka PPS, Mieczysława Niedziałkowskiego ${ }^{9}$, a także rozprawy i artykuły Andrzeja Jaeschke ${ }^{10}$, Jana Tomickiego ${ }^{11}$ oraz Stanisława Michałowskiego ${ }^{12}$. Warto wspomnieć również o biografiach ważnych pepeesowskich publicystów autorstwa Stanisława Sławomira Niciei ${ }^{13}$, Andrzeja Friszke ${ }^{14}$ czy Tadeusza Sierockiego ${ }^{15}$, a także o kilku ważnych przyczynkach Mariana Marka Drozdowskiego ${ }^{16}$.

Uwagę zwraca jednak fakt, że najważniejsze prace poświęcone myśli politycznej polskiego ruchu socjalistycznego $\mathrm{w}$ okresie międzywojennym - pióra wymienionych autorów - powstały zwykle przed 20 i więcej laty, w ostatnim czasie zaś nie prowadzono - poza nielicznymi wyjątkami - systematycznych badań źródłowych nad tą problematyka, nawet pomimo tego, że jednocześnie dała się zauważyć daleko idąca intensyfikacja badań nad ideowym dorobkiem innych obozów i środowisk obecnych na scenie politycznej II Rzeczypospolitej, często posiadających zresztą znacznie mniejsze wpływy niż socjaliści. Prezentowana rozprawa powstawała też wobec tego z przekonaniem, że podjęcie na nowo pogłębionych, opartych na szerokiej bazie źródłowej studiów nad dziejami polskiego ruchu socjalistycznego w okresie międzywojennym i poszukiwanie nowych interpretacji tej problematyki to zadania ważne oraz warte uwagi rodzimej historiografii. Zdaje się o tym przekonywać również wynik podjętej w omawianej rozprawie, stosunkowo wszak skromnej, próby.

W świetle przeprowadzonych analiz wyraźnie nasuwa się bowiem wniosek, że na początku lat trzydziestych polska (a zarazem europejska) myśl socjalistyczna weszła w fazę kryzysu; kryzysu oczywiście rozumianego nie jako drastyczne obniżenie się poziomu refleksji programowej (miało miejsce raczej zjawisko odwrotne), lecz kryzysu przyjmowanych w szeregach socjalistów w poprzednich latach teoretycznych założeń i opartych na nich strategicznych koncepcji. Lata dwudzieste, po tym jak przez kontynent przelała się już fala radykalnych nastrojów i ustały gwałtowne wybuchy społecznego niezadowolenia, upłynęły socjalistom $\mathrm{w}$ zasadzie pod znakiem historycznego optymizmu i głębokiej wiary w słuszność obranej tuż po wojnie drogi. Stary dylemat,

${ }^{9}$ M. Śliwa, Myśl polityczna Mieczysława Niedziatkowskiego (1893-1940), Warszawa 1980.

${ }_{10}$ Zob. np.: A. Jaeschke, Myśl społeczno-polityczna Zygmunta Zaremby w latach 1916-1967, Kraków 1992; idem, Główne elementy myśli politycznej polskiej lewicy socjalistycznej $w$ latach trzydziestych, „Studia Historyczne” 1988, t. III.

11 Zob. np.: J. Tomicki, Lewica socjalistyczna w Polsce 1918-1939, Warszawa 1982.

12 S. Michałowski, Myśl polityczna Polskiej Partii Socjalistycznej (1918-1939), Lublin 1994.

${ }^{13}$ S.S. Nicieja, Adam Próchnik. Historyk, polityk, publicysta, Warszawa 1986.

14 A. Friszke, Adam Ciotkosz. Portret polskiego socjalisty, Warszawa 2011.

15 T. Sierocki, Oskar Lange, Warszawa 1989.

${ }^{16}$ Zob. np.: M.M. Drozdowski, Ewolucja programu ekonomiczno-spotecznego Polskiej Partii Socjalistycznej od 1892 do 1992 roku, w: Stulecie Polskiej Partii Socjalistycznej 1892-1992, red. M.M. Drozdowski i in., Warszawa 1993, s. 85-101. 
zamknięty we frazie „reforma czy rewolucja?”, zdawał się ostatecznie rozwiązany - to nie sprzeczność czy alternatywa, jak się miało okazywać, lecz raczej dialektyczna jedność definiująca strategię ruchu socjalistycznego. Naznaczona ewolucjonizmem interpretacja marksizmu, wypracowana jeszcze $\mathrm{w}$ okresie II Międzynarodówki, z łatwością dała się dostosować do warunków działania w nowej, demokratycznej już, rzeczywistości powojennej. Na jej gruncie sformułowano w latach dwudziestych spójny i przekonujaccy model ewolucyjnej i zasadniczo pokojowej drogi do socjalizmu. Zasadzał się on m.in. na założeniu, że proces kształtowania obiektywnych, a więc gospodarczych przesłanek przyszłego ustroju zachodzi w sposób naturalny i niejako mimowolny na gruncie samej logiki rządzącej rozwojem kapitalizmu, a przejście pomiędzy nim a socjalizmem dokona się w sposób płynny, a wobec tego i w warunkach gospodarczej równowagi. W sposób najbardziej wyrafinowany takie przekonanie uzasadniała wspomniana teoria „kapitalizmu zorganizowanego” Hilferdinga, na której gruncie sam proces kształtowania przesłanek socjalizmu ulegał swoistej obiektywizacji, co dostarczało też dowodów koncentracji zainteresowania socjalistów przede wszystkim na wyborczych zmaganiach i na stopniowym zdobywaniu „wpływu na państwo”. W ten sposób torowana miała być również ku ostatecznej „socjalizacji”, zasadniczo ukształtowanej już przez sam kapitalizm nowej struktury efektywnej, planowej i poniekąd też uspołecznionej formy gospodarczej.

$\mathrm{W}$ podobnie ewolucjonistycznym duchu socjaliści postrzegali w latach dwudziestych proces przekształceń form politycznych, wierząc w zasadnicza nieodwracalność procesów demokratyzacji i oczekujac stopniowego rozszerzania form demokratycznych również na inne dziedziny życia społecznego. Stąd przez pewien czas skłonni byli postrzegać kolejne, pojawiające się na mapie kontynentu dyktatury, przede wszystkim jako epizody, krótkotrwałe skutki historycznych konwulsji, nieuniknionych w procesie przerastania starego porządku w nowy, już socjalistyczny. W tym, że proces ten konsekwentnie postępował będzie naprzód, a obok obiektywnych przesłanek socjalizmu ukształtują się również przesłanki subiektywne, utwierdzała również przyjmowana powszechnie w szeregach ruchu socjalistycznego koncepcja przyrostu „Świadomości politycznej”. Proces „uświadomienia” z definicji miał być jednokierunkowy i prowadzić w konsekwencji do rozpoznania rzeczywistego układu stosunków społecznych, a wobec tego i do działania politycznego poszczególnych jednostek, warstw i klas społecznych w zgodzie z ich „obiektywnym” interesem. To zaś z konieczności tworzyć winno, jak wierzono, korzystna koniunkturę dla trwałych, progresywnych reform społecznych.

Fakt, że wszystkie te procesy zdawały się zachodzić, świadczyć miał o tym, że nastał „okres przejściowy” pomiędzy kapitalizmem a socjalizmem, a to znów każdemu, choćby najmniejszemu, osiagnięciu ruchu nadawało sankcję „kroku” na drodze ku nowemu, wyczekiwanemu ustrojowi. W ten też sposób każda „reforma” stawała się drobną częścią wielkiej rewolucji społecznej. Rewolucji, 
której decydujące etapy, niosące realizację zasadniczych celów ruchu, zdawały się według socjalistów należeć jednak do przyszłości raczej odległej.

Wydarzenia przełomu lat dwudziestych i trzydziestych stanowiły bardzo poważne wyzwanie dla tej, zasadniczo optymistycznej i sprzyjającej swoiście pasywnej taktyce, koncepcji. Należy wobec tego zdecydowanie podkreślić, że ideowego przesilenia, którego doświadczyła w latach trzydziestych PPS, nie można traktować jedynie jako rezultatu radykalizacji nastrojów, charakterystycznej dla okresu kryzysu gospodarczego i dotykającej w jakimś stopniu wszystkie obozy obecne na polskiej scenie politycznej, czy też jako owocu frustracji i poczucia bezradności w związku z utrata jakiegokolwiek praktycznego wpływu na władzę. Jego przesłanki tkwiły również głębiej i wiązały się $\mathrm{z}$ napięciami występującymi w samej istocie nowoczesnego ruchu socjalistycznego oraz podejmowanymi wciąż na nowo próbami ich przezwyciężenia.

Aby dobrze zrozumieć przyczyny i szeroki teoretyczny kontekst przewartościowań programowych dokonujących się w szeregach PPS w latach trzydziestych, należy wyjść od wspomnianej już tezy o systemowym charakterze kryzysu kapitalizmu, sformułowanej ostatecznie latach 1930-1931, pociagała ona bowiem za sobą szereg ważkich konsekwencji dla strategii i taktyki, za która opowiadali się socjaliści. Dokonywana przez nich analiza przemian, jakim ulegać miał kapitalizm, prowadziła do wniosku, że na gruncie logiki rządzącej jego działaniem niemożliwe jest trwałe przywrócenie równowagi, a także efektywne wykorzystanie dostępnych zasobów i owoców postępu technologicznego. Uzupełniając te konkluzje opisem nowych form wyzysku, wynikających z procesów monopolizacji, a związanych przede wszystkim z konsumpcja, nie zaś z mechanizmem przechwytywania wartości dodatkowej w trakcie najemnej pracy fabrycznej, socjaliści stwierdzali, że kapitalizm staną $\mathrm{w}$ obiektywnej sprzeczności z aktualnymi interesami niemal wszystkich klas i warstw społecznych, a nie tylko robotników. Tak radykalny wniosek zdawała się zresztą w całej rozciagłości potwierdzać już tylko obserwacja kryzysowej rzeczywistości, nie zaskakuje więc, że przyjmowany był wśród socjalistów w zasadzie bez poważniejszej dyskusji.

Polityczne konsekwencje takiej tezy jednak trudno przecenić. Po pierwsze, zachwiać musiały się $\mathrm{w}$ takiej sytuacji tradycyjne mechanizmy legitymizacji kapitalizmu - skoro coraz powszechniejszy stawał się brak akceptacji dla tego systemu, to zrozumiałe okazywało się porzucenie przez burżuazję, jedyna klasę wciąż zainteresowaną w jego trwaniu, form demokracji politycznej. Tu więc tkwić miały, jak uważali socjaliści, społeczne źródła rozwijających się prądów dyktatorskich z faszyzmem, jako ich najbardziej radykalnym wcieleniem, na czele. Taki sposób definiowania faszyzmu - jako próby podtrzymania kapitalizmu przy użyciu przemocy i politycznego przymusu - prowadził zaś do wniosku, że być może nieuniknione stanie się dla klas pracujących sięgnięcie w konflikcie klasowym po przemoc i środki pozaprawne. Przedmiotem dyskusji socjalistów pozostawało jednak to, czy przemoc i gwałtowne metody 
walki stanowić mają jedynie środek defensywy, czy też w zaistniałej sytuacji zakładać można również ich użycie w akcji ofensywnej.

Teza o systemowym charakterze kryzysu kapitalizmu nie tylko zmuszała do przewartościowań w kwestii ram ustrojowych i form politycznych toczonej walki, lecz prowadzić musiała również do ponownego przemyślenia układu sił klasowych i roli, jaka do odegrania w toczacych się zmaganiach mają poszczególne klasy i warstwy społeczne. Optymizm socjalistów przez lata opierał się m.in. właśnie na przekonaniu, że rozwojowi gospodarki kapitalistycznej z konieczności towarzyszyć musi również postępująca proletaryzacja. W tym sensie starą Marksowska formułę o kapitalizmie, który mimowolnie stwarza swych własnych grabarzy, należało rozumieć niemal dosłownie. Jednak wejście kapitalizmu w fazę kryzysu strukturalnego oznaczało, jak twierdzili na początku lat trzydziestych socjaliści, że jego potencjał rozwojowy uległ wyczerpaniu, a procesy właściwej proletaryzacji zostały trwale wstrzymane. To zaś znaczyło, że walka o socjalizm toczyć będzie musiała się w obrębie aktualnie istniejącego układu sił klasowych, w ramach którego proletariat wciąż pozostaje mniejszością społeczeństwa. Jeśli więc walka ta miała zakończyć się sukcesem, a nowy ustrój oprzeć się na wyraźnej większości społeczeństwa, to u boku proletariatu powinny stanać również inne klasy i warstwy znajdujące się w relacji obiektywnego antagonizmu w stosunku do kapitalizmu. Dlatego właśnie na czoło problemów podejmowanych w publicystyce i programowych rozważaniach socjalistów wysuną się problem tzw. warstw pośrednich i sposobów ich politycznej mobilizacji, jeszcze kilka lat wcześniej traktowany co najwyżej marginalnie.

Również za zmianami stanowisk w kwestii metod działania i taktyki oraz różnymi preferencjami socjalistycznych przywódców i publicystów różnych haseł i politycznych scenariuszy, do których realizacji należało dążyć, kryły się też rozbieżności o bardziej zasadniczym, teoretycznym charakterze. Dobrze widoczne jest to zwłaszcza na przykładzie sposobu definiowania przyczyn kryzysu kapitalizmu - objaśnienie oferowane przez Oskara Lange, a z czasem przyjęte przez wielu działaczy o radykalnej orientacji, nie pozostawiało nadziei na gospodarcza stabilizację bez politycznej rewolucji i szybkiego wywłaszczenia wielkiej i średniej własności, co znajdowało znów bezpośrednie odbicie również w formułowanych hasłach czy taktycznych koncepcjach. Bardziej popularne w publicystyce PPS wyjaśnienia mechanizmu kryzysowego, skoncentrowane wokół zjawiska tzw. podkonsumpcji, stanowić mogły natomiast z powodzeniem punkt wyjścia bardziej umiarkowanych propozycji akcentujących konieczność głębokich zmian w sposobie podziału dochodu społecznego, lecz jednocześnie dających się pogodzić z mniej pryncypialnym stanowiskiem w kwestii taktyki i tempa mającej się dokonać w przyszłości transformacji stosunków społeczno-gospodarczych. Podobnie subtelne różnice w kwestii oceny sił klasowych i możliwych sposobów mobilizacji tzw. warstw pośrednich również wiązały się $\mathrm{z}$ istotnymi rozbieżnościami $\mathrm{w}$ formułowanych 
propozycjach działania. Część socjalistów wyciagała bezpośrednie wnioski taktyczne z fundamentalnego założenia o wyjątkowości historycznej roli klasy robotniczej, wierząc, że działając z rewolucyjnym rozmachem, pociagnie ona za sobą resztę społeczeństwa. Inni - najbardziej przekonującym stronnikiem tego stanowiska stał się Niedziałkowski - nie odmawiali zasadniczej podmiotowości politycznej tzw. warstwom pośrednim, a w związku z tym bliższa była im raczej logika koalicji jako podstawy wieloklasowego bloku walczącego z kapitalizmem.

W sposób najbardziej wyrazisty różnice stanowisk w szeregach PPS uzewnętrzniły się $\mathrm{w}$ toku prac nad nowym programem partii. Choć zgłoszone projekty - pierwszy autorstwa działaczy o bardziej radykalnej orientacji, szafujący rewolucyjną retoryka, drugi zaś pióra Niedziałkowskiego, popierany też przez kierownictwo PPS - sporo różniło, to jednak obydwa stanowiły próbę odnalezienia odpowiedzi na kryzys, który na początku lat trzydziestych dotknął myśli socjalistycznej. Ostatecznie jednak spoza zgiełku polemik i gwałtownych często sporów wyłania się - jak wynikałoby $\mathrm{z}$ przeprowadzonych $\mathrm{w}$ rozprawie analiz - pewien bardziej ogólny kierunek przewartościowań zachodzących w polskiej myśli socjalistycznej tego okresu, homologicznych zreszta pod wieloma względami z przemianami zachodzącymi również w innych europejskich partiach socjalistycznych (a opisywanych m.in. przez Sheri Berman ${ }^{17}$, Gerda-Rainera Horna ${ }^{18}$ czy Adama Przeworskiego ${ }^{19}$ ). Przede wszystkim zauważyć można stopniowe porzucanie, odziedziczonego jeszcze po złotych latach II Międzynarodówki, historycznego determinizmu i przejście od zasadniczo pasywnej strategii pomnażania własnych sił oraz oczekiwania, aż dojrzeja przesłanki socjalistycznej transformacji, do poszukiwania metod działania, bezpośrednio przybliżających do ustanowienia nowego, socjalistycznego ładu. I choć różnie sobie w szeregach PPS wyobrażano jego kształt oraz drogi doń prowadzące, to wysunięte w programie radomskim hasło „Polskiej Rzeczypospolitej Socjalistycznej” nie było jedynie retorycznym ornamentem, lecz świadectwem aktywistycznego zwrotu w polskiej myśli socjalistycznej i symptomem dokonujących się w dekadzie lat trzydziestych na różnych poziomach przemian w programowych koncepcjach PPS.

\footnotetext{
${ }^{17}$ S. Berman, The Social Democratic Moment. Ideas and Politics in the Making of Interwar Europe, Cambridge 1998.

${ }_{18}$ G.R. Horn, European Socialists Respond to Fascism. Ideology, Activism and Contingency in the 1930s, New York 1996.

19 A. Przeworski, Socialism and Democracy, New York 1985.
} 